\title{
Enlightenment of Differences between Chinese and American Modes of Thinking in English Teaching in Universities and Colleges
}

\author{
Xiong Guofang* \\ School of Foreign Language of Xi'an University \\ Xi' an, China \\ 357141898@qq.com \\ * Corresponding Author
}

\begin{abstract}
Different modes of thinking reflect differences in language expressions, and differences between Chinese and American modes of thinking are important factors influence English teaching and learning in universities and colleges as well. Therefore, this paper discusses the differences between Chinese and American modes of thinking and these differences on English teaching in universities and colleges in the aspects of vocabularies, sentences and texts as well as negative transfer of differences in modes of thinking on English learning. The purpose of this paper is to propose some implications of differences between Chinese and English modes of thinking for English teaching and learning in universities and colleges. This paper is a documentary and qualitative research. It can be resulted from this paper that the basic goals of English teaching in universities and colleges are training students' modes of thinking and strengthening their senses of language, and teachers in universities and colleges should make full use of Chinese and English different modes of thinking in order to improve English teaching effect in universities and colleges as well as constantly improve students' comprehensive abilities of using English in daily communications.
\end{abstract}

Keywords-modes of thinking; Chinese and American; English teaching; universities and colleges

\section{INTRODUCTION}

Mode of thinking is closely related to language, and it is an important factor of restricting language forms. Differences in modes of thinking are the causes linguistic and cultural differences, and certain cultural thinking modes are also contained in language forms as well. All countries in the whole world have their own histories, and different histories also shape different modes of thinking. Besides, mode of thinking also control and has influence on language expressions of human beings. Moreover, there are also differences in people's cognitive modes of outer world between China and America so that they will also have influence on Chinese and American modes of thinking. In this way, this will be not only reflected in the characteristics of language, but also it is embodied in the use of language as well. As a result, this paper makes an analysis of differences between Chinese and English modes of thinking and their influence on English teaching and learning in universities and colleges so as to improve English teaching effect in universities and colleges and cultivate students' comprehensive abilities of using English in daily communication.

\section{DIFFERENCES BETWEEN CHINESE AND ENGLISH MODES OF THINKING}

The following part discusses the specific differences between Chinese and American modes of thinking.

\section{A. Imaginal Thinking and Abstract Thinking}

From the overall situation it can be seen that traditional Chinese cultural mode of thinking has strong concreteness, but western cultural mode of thinking has strong abstract characteristics. Imaginal thinking is reflected in Chinese words, sentences and texts, and only a imaginal word can describe a complete scene so that readers can have a clear understanding of the author. As a result, abstract thinking of Chinese people is relatively developed, and they pay more attention to practical experience, so that they often understand and grasp inner nature and rules of things with the help of intuitions. However, English is a kind of phonetic language, and word meanings do not have a direct relationship with word forms, so that they pay attention to rational abilities as well as logical thinking. In western mode of thinking, people pay more attention to the integrity of sentences, thus English is used in various forms.

\section{B. Overall Thinking and Analytical Thinking}

Human and nature are in are in an organic whole in the view of Chinese traditional concept, and Chinese culture starts from the integrity, then various parts are developed and the whole is beyond all parts so that they pay attention to collectivism. Chinese belongs to overall thinking, and it always begins from the whole to the individual parts. English mode of thinking is opposite to Chinese mode of thinking, and they often start from parts to the whole. English mode of thinking is analytical, and there is a big difference between Chinese and English modes of thinking so that it brought difficulty to students' English learning in universities and colleges.

\section{Linear Thinking and Spiral Thinking}

Mode of thinking refers to a kind of inherent language sequence of expressing ideas, and Chinese and English both reflect characteristics of modes of thinking and styles of different countries. Besides, they also reflect social, cultural and psychological trends of China and America as well. English linear thinking belongs to linear thinking, and this kind of mode of thinking firstly originated from history and culture of Plato, Aristotle and ancient Greek. 
This kind of persuasive speech is direct, and all steps are linked to one another. Its influence on rhetorical forms is reflected in English that English people are idiomatic to use topic sentences in English paragraphs. They are direct in showing their ideas, and then they discuss it in detail, so a conclusion is made at last. Mode of thinking from general to specific is used in English learning in universities and colleges. Chinese people belong to spiral thinking, so that mode of thinking from specific to general is used in English writing by Chinese people.

\section{INFLUENCE OF DIFFERENCES BETWEEN CHINESE AND ENGLISH MODES OF THINKING ON ENGLISH TEACHING IN UNIVERSITIES AND COLLEGES}

The following part discusses the influence of differences between Chinese and English modes of thinking on English teaching in universities and colleges including writing teaching and translation activities.

\section{A. Influence on English Writing}

Under the influence of Chinese mode of thinking, Chinese comes into students mind in forms of words, sentences or texts in the process of English writing, and they quickly finish English writing through translation from Chinese to English. They regard English writing in universities and colleges as a process of C-E translation, so that it is difficult for them to use learnt English knowledge in the process of English writing better and proficiently. It can be found that most students express their ideas in English writings with the help of Chinese, and Chinglish in English writing of students in universities and colleges. Sometimes there will be more mistakes under the influence of different modes of thinking between China and America for those students who are weaker in basic knowledge.

\section{B. Influence on Translation Activities}

Chinese people are imaginal thinking and they pay attention to the integration of subjects and objects. However, American people are abstract thinking, and they pay attention to the oppositeness of subjects and objects. Chinese people tend to pursue the integration of objective sceneries and subjective emotions as well as feelings, and English represents sceneries with the help of specific images. Therefore, English words and sentences and simple, objective and concise. As a result, students in universities and colleges tend to ignore differences between Chinese and English modes of thinking, and they only pay attention to the equivalence of words and sentences, European Chinese and Chinglish will come into being.

Most mistakes in English writing and translation activities of students in universities and colleges are caused by differences between Chinese and English modes of thinking, so that teachers should pay attention to systemic explanations of differences between Chinese and English modes of thinking in universities and colleges so as to guide students in English teaching in universities and colleges. It can be clearly seen from the following chart.

\begin{tabular}{|l|l|l|l|l|}
\hline Mistakes & Reading & Writing & Translation & \\
\hline$\%$ & $15 \%$ & $40 \%$ & $45 \%$ & \\
\hline
\end{tabular}

\section{WAYS OF CULTIVATION OF ENGLISH MODE OF THINKING IN ENGLISH LEARNING IN UNIVERSITIES AND COLLEGES}

Teachers should design classroom teaching activities elaborately, and they should proper training methods of modes of thinking for students at proper moment in universities and colleges. Besides, teachers should also select suitable teaching materials from textbooks and other materials to improve students' English mode of thinking in the process of English teaching in universities and colleges.

\section{A. Teachers' Guide}

As guide and help of students, teachers should help students have a better understanding of language differences caused by different modes of thinking with vivid and humorous language so as to promote input of English. In terms of students' mistakes such as adverbial modifier in the beginning of sentences, more use of short sentences and less use of long sentences as well as obvious colloquial trend, teachers should also make an analysis of reasons from the angle of differences between Chinese and English modes of thinking. At the same time, this can also improve students' consciousness and ability in translation and English speaking.

\section{B. Cultivation of Sense of English}

Teachers should also cultivate students' sense of English and encourage read more authentic English passages. Teachers can design learning plans of strong practicality for students in universities and colleges to improve students' sense of English as mush as possible in the process of English teaching. Besides, universities and colleges should also provide real English learning environment for students so that they relevant activities of training students' mode of thinking in universities and colleges can be promoted.

\section{Strengthening Translation Teaching in Universities and Colleges}

Translation teaching is very important in English teaching in universities and colleges, and C-E translation is also the weak link of Chinese students in the process of English learning, so that students in universities and colleges should try more efforts in translation learning. Under the influence of Chinese mode of thinking, C-E translation of students are mostly not corresponding to English mode of thinking, and words as well as sentence structures used by students are also stiff and hard to pronounce. Therefore, teachers should point out the improper phenomenon of students in C-E translation in universities and colleges, and they should encourage students learn lessons from their mistakes so that they can gradually get rid of the constraints of Chinese mode of thinking and C-E translation quality of them can also be improved at the same time.

\section{CONCLUSION}

In conclusion, teachers should help students recognize differences between Chinese and American modes of thinking and make full use of differences between Chinese and English modes of thinking in English teaching in universities and colleges in order to improve English 
teaching and learning effect as well as improve students' comprehensive abilities of using English in universities and colleges. Besides, teachers should also give guidance for students to correct their mistakes in reading, writing and translation. Moreover, explanations of comparison of Chinese and English modes of thinking in the process of English teaching and learning in universities and colleges so that students can get rid of interference of mode of thinking of mother tongue and their language abilities can be truly improved at the same time.

\section{REFERENCES}

[1] Fries, C. Teaching and Learning English as a Foreign Language. MI: University of Michigan Press. 1945.

[2] Hoey, Michael. Textual Interaction. Londoand New York: Routledge. 2001.

[3] Kachru, B. The Other Tongue: English Across Cultures. Urbana IL University of Illinois Press. 1982
[4] Krashen, S. D. Second Language Acquisition and Second Language Learning. Oxford: Pergamon Press. 1981.

[5] Lian Shuneng. On Chinese and Western Modes of Thinking [M] Chinese and English Comparison and Translation, Shanghai Foreign Language Education, 2002.

[6] Martin, J. R. English Text System and Structure. Beijing: Peking University Press 2004.

[7] Mc Carthy, M. Analysis for Language Teachers. Shanghai: Shanghai Foreign Language Education Press. 1991.

[8] Ouyang Zhiqun. The Influence of Chinese and English Modes of Thinking on English Teaching in Universities and Colleges [J]. Professional Education, 2013.

[9] Paltridge, B. Genre, text type, and the language learning classroom. EFL Journal. 50 (3): 237-243. 1996.

[10] Winter, E. O. Clause Relations as Information Structure: Two Basic Text Structures in English. In M. Coulhard(ed.), Advances in Written Text Analysis. London: Routledge. 1994 